Check for updates

The BMJ

Cite this as: BMJ 2021;374:n2270

http://dx.doi.org/10.1136/bmj.n2270

Published: 15 September 2021

\title{
Covid-19: Government lays out its "plan B" to protect NHS this winter
}

\section{Gareth lacobucci}

Ministers will reintroduce a range of precautionary measures against covid-19 this autumn and winter if a further surge in cases threatens to overwhelm the NHS.

The government's plan, ${ }^{1}$ published on 14 September, sets out what it calls a "plan B for England" that it will initiate if data suggest the NHS is likely to come under unsustainable pressure during the coming months.

Measures would include introducing mandatory vaccine certification in specific settings, bringing back the legal requirement to wear face coverings in some settings, and advising people to work from home if they are able to. The government said it was committed to taking "whatever action is necessary" to protect the NHS from being overwhelmed but said stricter economic and social restrictions such as lockdowns would only be considered as "a last resort."

“The government's plan B prioritises measures which can help control transmission of the virus while seeking to minimise economic and social impacts," it says.

Announcing the plan in the House of Commons, England's health secretary Sajid Javid said there was no single metric that would trigger plan $\mathrm{B}$, but he said that data on hospital admissions, ratio of cases to hospital admissions, and the trajectory of new cases would all be monitored closely. "Any responsible government must prepare for all eventualities, and although these measures are not an outcome anyone wants, it's one that we need to be ready for just in case,” Javid said.

Deputy chief executive of NHS Providers, Saffron Cordery, said the "pragmatic approach" was welcome given the ongoing pressure on hospitals. She said, "Trusts are grappling with record waiting lists across hospital, mental health, and community services. Bed capacity is lower because of continuing enhanced infection control measures. Staffing levels and burnout continue to be a critical concern for many trusts.

"Demand for urgent and emergency care is above pre-pandemic levels, with unprecedented pressures on ambulance services and more people severely ill requiring complex care. And that's before the usual winter pressures kick in, which could be made even more challenging with rising levels of flu, respiratory syncytial virus, and covid-19.”

However, Chaand Nagpaul, BMA council chair, questioned whether delaying action was the right move. With 50 ooo doctors short going into the winter, the evidence suggested that vaccines alone would not be sufficient to stem the rise in infections.
"The UK government introduced restrictions last October because they were rightly worried that there were more than 1000 covid patients in hospital-today we have more than 8000 covid patients in hospital and 50\% more patients in intensive care," he said.

"The UK government is advising the public to meet outdoors where possible and to wear masks in crowded indoor spaces-they clearly believe these simple measures do make a difference yet are failing to act by making these a requirement. We've had this kind of double speak before, which has resulted in action not being taken until it is too late. Metric tigger points should have been, and must still be, considered.

“While ministers speak of a 'plan B'-although on what basis is unclear-they should open their eyes and realise that now is the time to act. If left too late, we could find ourselves in a position where the NHS is dangerously overwhelmed, returning to a situation where ambulances were queueing round corners and hospitals had no choice but to pause all elective care, further increasing the already enormous backlog."

1 HM Government. Covid-19 response: autumn and winter plan. September 2021. https://assets.publishing.service.gov.uk/government/uploads/system/uploads/attachment_data/file/1017404/COVID-19-response-autumnand-winter-plan-2021.pdf.

This article is made freely available for use in accordance with BMJ's website terms and conditions for the duration of the covid-19 pandemic or until otherwise determined by BMJ. You may use, download and print the article for any lawful, non-commercial purpose (including text and data mining) provided that all copyright notices and trade marks are retained. 